\title{
Results of Study of the Reference Value of Enzyme Alanine Aminotransferase in Mongolian Adults
}

\author{
Ganchimeg $\mathrm{Ch}^{* 1}$ and Odontuya $\mathrm{D}^{2}$ \\ ${ }^{1}$ Teacher of Biochemistry and Laboratory Department, School of Biomedicine, Mongolia \\ ${ }^{2}$ Honorary professor of the Family Medicine Department, School of Medicine, Mongolia
}

*Corresponding author: Ganchimeg $\mathrm{Ch}$, Teacher of Biochemistry and Laboratory Department, School of Biomedicine, Mongolia

\section{ARTICLE INFO \\ Received: 幽 March 22, 2019 \\ Published: 㓞 March 27, 2019 \\ Citation: Ganchimeg Ch, Odontuya D. Results of Study of the Reference Value of Enzyme Alanine Aminotransferase in Mongolian Adults. Biomed J Sci \& Tech Res 16(3)-2019. BJSTR. MS.ID.002858.}

Keywords: Enzyme; Reference Value; Alanine Aminotransferase; Healthy Adults; Mean Value

\author{
ABSTRACT
}

Introduction: In 1992 Medical Institute of Mongolia studied reference value of Alanine aminotransferase (ALAT) Mongolian population, but used old chemical methods and old analyzers.

Goal: To study the reference value of enzyme ALAT in the serum of Mongolian adults' blood and its correlation with some dependent factors.

Methods of study: We included 3742 healthy adults from six regions in our survey. In each age group of the research included at least 30 specimens. The design of the study was instantaneous research model of WHO. The reference value developed by the International Committee of Reference for International Treasury Recommendations (LIMO), which was adapted to the specifics of Mongolia.

Results: Average activity of ALAT enzymes / Table 1/ within population is $23.55 \pm$ $0.29 \mathrm{U} / \mathrm{L}$; for males $-28.50 \pm 0.50 \mathrm{U} / \mathrm{L}$; for female $-19.87 \pm 0.32 \mathrm{U} / \mathrm{L}$. The reference value of the enzyme ALAT for population is 4.55-42.55 U/L; for men 8.62-48.38 U/L for women 5.26-34.28 U/L. The mean levels of ALAT enzyme in the serum of men is higher than in women for all age.

Conclusion: The reference value of the enzyme ALAT for population is 4.55-42.55 $\mathrm{U} / \mathrm{L}$; for men 8.62-48.38 U/L for women 5.26-34.28 U/L. ALAT enzyme activity correlated with sex, season and not correlated with regions.

\section{Introduction}

In 1992 Medical Institute made study of reference amount of Aspartate aminotransferase (ASAT), Alanine aminotransferase (ALAT), Gamma glutamine transpeptidase (GGT), Lactate dehydrogenase (LDG) within Mongolian adults using traditional chemical tests, but in modern medicine, when we use automat analyses for testing the old references maybe not appropriate to use. In Mongolian hospital's laboratories people still continue use references established in foreign population, or use references proposed by firms and companies, which produced and exported reagents. These references do not include physiological features of Mongolian people, their age, sex, season, regional differences. Mongolian clinical diagnostic laboratories have to reestablish or renew clinical, biochemical reference value of biochemical tests of Mongolian people.

\section{Goal of the Study}

To study the reference value of enzyme ALAT in the serum of Mongolian adults' blood and its correlation with some dependent factors.

\section{Objectives of the Study}

a) To study the reference value of enzyme ALAT in the blood serum of Mongolian adults and determine the maximal and minimal values. 
b) To study the reference value of enzyme ALAT in the blood serum of Mongolian adults and its correlation with age and sex.

c) To study the reference value of enzyme ALAT in the blood serum of Mongolian adults and its correlation and differences in regions and seasons.

\section{Materials and Methods of Study}

A total of 3742 people was surveyed, in each age group of the biomedical research included at least 30 specimens, and confidence level 98\% ( $\mathrm{t}=2.33)$, and result of error $0.02=2 \%$. The design of the study was WHO's study instantaneous model research design by step by step. The reference value developed by the International Committee of Reference for International Treasury Recommendations (LIMO), which was adapted to the specifics of Mongolia and study provided in three steps. Age groups of the study were 16-20, 21-25, 26-30, 31-35, 36-40, 41-45, 46-50, 51$55,56-60,61-65$, more than 66 . Regions were divided in 6 groups: Altai (mountain) region, Khangai (Forest) region, Step region, Gobi Desert region, Central region, Ulaanbaatar region. The study was conducted in accordance with the International Guidelines "Ethical aspects for the Biomedical Survey", and the general principles of biomedical research.

\section{Methodology of Study}

Identification of the enzyme Alanine Aminotransferase (ALAT) provided by the standard method using the reinforced liquid test kits produced by Roshe (Korea), Human (Germany) and Hospitex (Italy ), and used an automated analyzers produced by the International Clinical Biochemical Association KINETIC COLOROMETRIC (IFCC).

\section{Statistical Processing}

The results of the study were developed using the Microsoft Excel and SPSS-17 standard software, mathematical average $\mathrm{M}, 95 \%$ of the mean probability of deviations from $\mathrm{M} \pm \mathrm{m}, 95 \%$ probability of change (CI 95\%), and the intermediate limit of references. Determined the maximum and minimum limit value, the value of the statistical significance $(p<0.05)$, and the mean value of the references determined by the Students' $t$ criterion. The correlation between enzymatic activity and age-related data was determined by the correlation test method.

\section{Results of Study}

The following Table 1 shows the 95\% confidence interval of the activity of the ALAT enzyme in the blood of healthy population , level $\mathrm{M} \pm \mathrm{m}$, the $95 \%$ probability (CI $95 \%$ ) required for the determination of activation rates was determined by the population (N) and gender. Average activity of ALAT enzymes / Table 1/ within population is $23.55 \pm 0.29 \mathrm{U} / \mathrm{L}$; for males $-28.50 \pm 0.50 \mathrm{U} / \mathrm{L}$; for female $-19.87 \pm 0.32 \mathrm{U} / \mathrm{L}$. The reference value of the enzyme ALAT for population is 4.55-42.55 U/L; for men 8.62-48.38 U/L for women 5.26-34.28 U/L.The mean levels of ALAT enzyme in the blood serum of men is higher than in women. Table 2 shows how the activity of ALAT enzyme level in the blood of Mongolian population differs from the age group and sex. The dependence of the ALAT enzyme activity from the age was determined by Student $t$ value, and the dependence from age of this enzyme was is statistically significant $(<0.0001)$. The value of the estimated criteria $/ t=14.53 /$ is the level of significance level corresponding to $<0.0001$. It means that ALAT value within male is higher than within female with the probability $\mathrm{P}>0.9999$. (Figure 1) illustrates how the activity of ALAT enzyme in the blood of population in Mongolia is dependent on the age and gender.

Table 1: Reference value of ALAT enzyme activity (U/L).

\begin{tabular}{|c|c|c|c|}
\hline & $\begin{array}{c}\text { Number of } \\
\text { people, }\end{array}$ & \multicolumn{2}{|c|}{$\begin{array}{c}\text { The mathematical mean of the ALAT } \\
\text { enzyme deviation with 95\% probability }\end{array}$} \\
\hline Sex & $(\mathrm{N})$ & $(\mathrm{M} \pm \mathrm{m})$ & $\mathrm{CI} 95 \%$ \\
\hline Men & 1597 & $28.50 \pm 0.50$ & $8.62-48.38$ \\
\hline Women & 2145 & $19.87 \pm 0.32$ & $5.26-34.48$ \\
\hline Total & 3742 & $23.55 \pm 0.29$ & $4.55-42.55$ \\
\hline
\end{tabular}

Note: CI 95\%- The minimum and maximum value of enzyme ALAT.

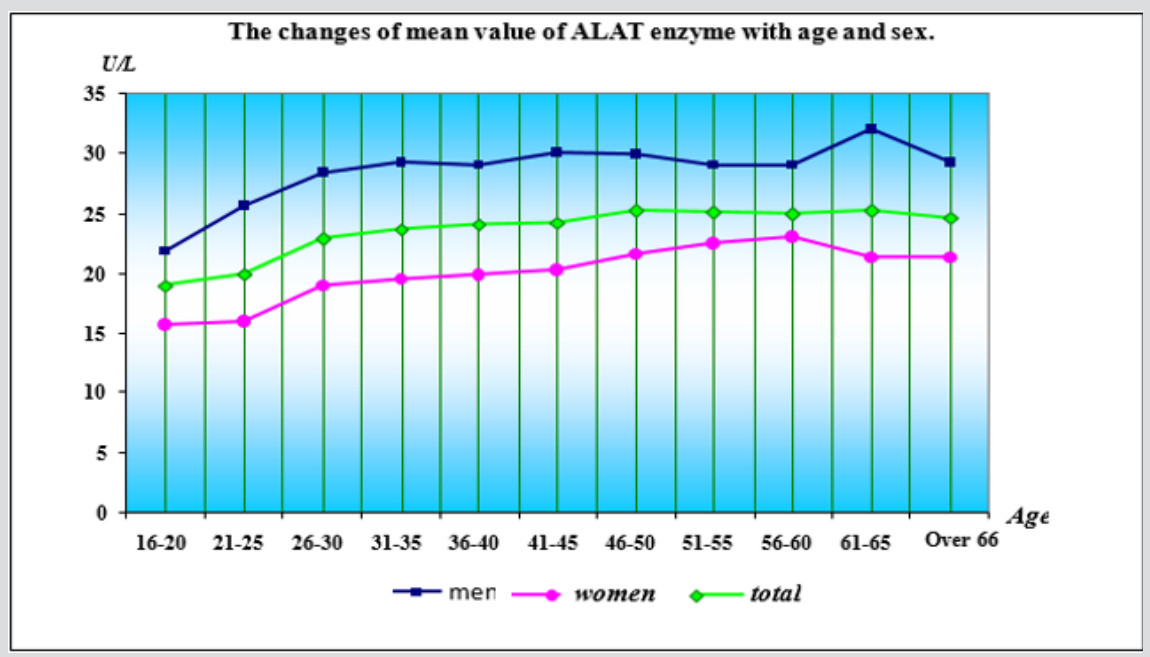

Figure 1: The changes of mean value of ALAT enzyme with age and sex. 
Table 2: The level of ALAT enzyme activity determined by age and $\operatorname{sex}(\mathrm{U} / \mathrm{L})$.

\begin{tabular}{|c|c|c|c|c|}
\hline Age & Sex & $\mathbf{N}$ & $M \pm m$ & CI 95\% \\
\hline \multirow{3}{*}{$16-20$} & man & 120 & $21.80 \pm 1.90$ & $1.22-42.40$ \\
\hline & women & 110 & $15.70 \pm 1.50$ & $0.00-31.4$ \\
\hline & total & 230 & $18.91 \pm 1.15$ & $1.46-36.36$ \\
\hline \multirow{3}{*}{$21-25$} & man & 143 & $25.60 \pm 1.71$ & $5.20-48.0$ \\
\hline & women & 205 & $15.90 \pm 0.99$ & $1.76-30.04$ \\
\hline & total & 348 & $19.94 \pm 0.94$ & $0.53-39.35$ \\
\hline \multirow{3}{*}{$26-30$} & man & 194 & $28.40 \pm 1.41$ & $8.82-47.97$ \\
\hline & women & 230 & $18.90 \pm 1.00$ & $3.65-34.14$ \\
\hline & total & 424 & $22.80 \pm 0.94$ & $2.81-42.91$ \\
\hline \multirow{3}{*}{$31-35$} & man & 205 & $22.90 \pm 1.40$ & $9.10-49.29$ \\
\hline & women & 278 & $19.50 \pm 0.84$ & $5.57-33.42$ \\
\hline & total & 483 & $23.67 \pm 0.98$ & $4.39-42.94$ \\
\hline \multirow{3}{*}{$36-40$} & man & 250 & $29.00 \pm 1.18$ & $11.34-46.66$ \\
\hline & women & 309 & $19.90 \pm 0.81$ & $5.68-34.12$ \\
\hline & total & 559 & $24.04 \pm 0.78$ & $5.49-42.58$ \\
\hline \multirow{3}{*}{$41-45$} & man & 216 & $30.10 \pm 2.07$ & $11.63-48.56$ \\
\hline & women & 295 & $20.30 \pm 0.88$ & $6.09-34.50$ \\
\hline & total & 511 & $24.51 \pm 0.83$ & $5.80-43.21$ \\
\hline \multirow{3}{*}{$46-50$} & man & 165 & $29.90 \pm 1.47$ & $11.06-48.74$ \\
\hline & women & 208 & $21.50 \pm 0.94$ & 8.04-34.96 \\
\hline & total & 373 & $25.27 \pm 0.94$ & $7.30-43.24$ \\
\hline \multirow{3}{*}{ 51-55 } & man & 117 & $29.00 \pm 1.92$ & $8.28-49.72$ \\
\hline & women & 186 & $22.5 \pm 0.99$ & $9.10-35.89$ \\
\hline & total & 303 & $25.04 \pm 1.01$ & $7.32-42.75$ \\
\hline \multirow{3}{*}{$56-60$} & $\operatorname{man}$ & 72 & $29.00 \pm 2.12$ & $10.70-47.29$ \\
\hline & women & 147 & $23.00 \pm 1.08$ & $10.00-35.99$ \\
\hline & total & 219 & $24.99 \pm 1.07$ & $9.05-40.93$ \\
\hline \multirow{3}{*}{$61-65$} & man & 47 & $32.00 \pm 2.54$ & $14.61-49.38$ \\
\hline & women & 82 & $21.30 \pm 1.52$ & $7.61-34.98$ \\
\hline & total & 129 & $25.20 \pm 1.60$ & 7.04-43.36 \\
\hline \multirow{3}{*}{$66 \leq$} & man & 68 & $29.20 \pm 2.47$ & $8.86-49.53$ \\
\hline & women & 95 & $21.30 \pm 1.00$ & 8.97-33.62 \\
\hline & total & 163 & $24.67 \pm 1.40$ & $6.83-42.51$ \\
\hline Total & 3742 & & $23.55 \pm 0.29$ & $4.55-42.55$ \\
\hline
\end{tabular}

Note: CI 95\% - the minimum and maximum reference value of the enzyme ALAT.

The results of our study show that ALAT enzyme in the blood serum is always higher in Mongolian men than in Mongolian women of all ages. Also, the activity of ALAT enzyme have tendency to decline in men after 46 and women after 55-60 years. The Table 3 below shows the mathematical meanings of ALAT enzyme activity by region and its $95 \%$ confidence interval, and the minimum and maximum values for the region. When determining the activity of ALAT enzyme in population of different regions, the mathematical mean is $22.56-24.08 \mathrm{U} / \mathrm{L}$, the minimum reference value is 4.19 -
$5.23 \mathrm{U} / \mathrm{L}$, and the maximum reference value is $40.78-43.26 \mathrm{U} / \mathrm{L}$. The ALAT enzyme activity differences on the regions determined by Student $t$ value, and the result $\mathrm{p}=0.153$ shows that the ALAT level does not different in regions. The seasonal difference of ALAT enzyme within population shown in Table 4.The reference value of ALAT enzyme math mean (20.69 U / L) and maximum value (37.23 $\mathrm{U} / \mathrm{L}$ ) is lower during the fall and higher in the winter and spring (with $\mathrm{M}=24.31 \mathrm{U} / \mathrm{L}$ and $43.32 \mathrm{U} / \mathrm{L}$ respectively). The value of ALAT enzyme is significantly different from the seasons, and is relatively low in the autumn ( $\mathrm{p}<0.0001)$ (Table 4). According to our study, the mathematical average of ALAT enzyme level in Mongolians blood plasma was estimated at $\mathrm{P}=0.95$ to $23.55 \pm 0.29 \mathrm{U} / \mathrm{L}$, for men 28.50 $\pm 0.50 \mathrm{U} / \mathrm{L}$, for women $19.87 \pm 0.32 \mathrm{U} / \mathrm{L}$. The reference value of ALAT enzyme for total population is $4.55-42.55 \mathrm{U} / \mathrm{L}$, for men 8.62$48.38 \mathrm{U} / \mathrm{L}$, for women 5.26-34.28 U/L, and the significance level difference between men and women is $\mathrm{p}<0.0001$.

Table 3: Study of ALAT enzyme level within population of different region of Mongolia (U/L).

\begin{tabular}{|c|c|c|c|}
\hline Regions & $\mathbf{N}$ & $\mathbf{M} \pm \mathbf{m}$ & $\mathbf{C I} \mathbf{9 5 \%}$ \\
\hline Gobi Desert & 402 & $22.56 \pm 0.91$ & $4.34-40.78$ \\
\hline Khangai & 836 & $23.53 \pm 0.65$ & $4.19-42.87$ \\
\hline Step & 396 & $24.00 \pm 0.97$ & $4.74-43.26$ \\
\hline Central & 658 & $24.03 \pm 0.74$ & $5.23-42.82$ \\
\hline ULaanbaatar & 1450 & $23.50 \pm 0.50$ & $4.48-42.52$ \\
\hline Total & 3742 & $23.55 \pm 0.29$ & $4.55-42.55$ \\
\hline
\end{tabular}

Note: CI 95\% - the minimum and maximum reference value of the enzyme activity.

Table 4: The level of ALAT enzyme in Mongolian population in different seasons $(\mathrm{U} / \mathrm{L})$.

\begin{tabular}{|c|c|c|c|}
\hline Seasons & $\mathbf{N}$ & $\mathbf{M} \pm \mathbf{m}$ & $\mathbf{C I} \mathbf{9 5 \%}$ \\
\hline Winter & 893 & $24.31 \pm 0.64$ & $5.30-43.32$ \\
\hline Spring & 1338 & $24.09 \pm 0.54$ & $4.59-43.60$ \\
\hline Summer & 1099 & $23.34 \pm 0.56$ & $4.48-41.30$ \\
\hline Autumn & 412 & $20.69 \pm 0.81$ & $4.16-37.23$ \\
\hline Total & 3742 & $23.55 \pm 0.29$ & $4.55-42.55$ \\
\hline Total & 3742 & $23.55 \pm 0.29$ & $4.55-42.55$ \\
\hline
\end{tabular}

Note: CI 95\% - the minimum and maximum reference value of the enzyme activity.

\section{Discussion}

Results of our study show that activity of ALAT enzyme is dependent on human sex, and it is higher within men than women. This results are similar to the studies provided by researcher Sherwin JE, Tietz NW, Moss DW, German researcher Gerhard Schumann, Japanese researcher Kiyoshi Ichihara, American researcher Brain Jorj, and Korean Kui Son Choi. According to our study, the minimum active value of ALAT enzyme was $3 \mathrm{U} / \mathrm{L}$, and the maximum was $48 \mathrm{U} / \mathrm{L}$ for males and $41 \mathrm{U} / \mathrm{L}$ for females. The table below shows the comparative analysis of the ALAT enzyme 
activity we have set for other researchers. As shown in Table 5, our findings are similar to the results of and Medical Research Institute [1-9]. Our results are different from the results of other researchers. Experimental results of Russian scientists [10-12]who used old chemical Writman-Fenkel and Bodansky methods were different from ours. The results of the 1992 of the Mongolian Institute of Medical Research, which conducted on Mongolians were similar to ours, but the level of activity of women's blood ALAT was higher , possibly due to the fact that studies conducted on fewer individuals and used traditional chemical methods.

Table 5: Comparison of Reference value of ALAT enzyme (U/L) in our and foreign studies.

\begin{tabular}{|c|c|c|c|c|}
\hline Researches & Years & Value & Men & Women \\
\hline Our study & 2009 & $4.55-42.55$ & $8.62-48.38$ & $5.26-34.28$ \\
\hline Mongolian Medical Institute & 1992 & $8.4-50.4$ & $8.4-49.8$ & $7.8-51.0$ \\
\hline Kui Son Choi, Korean & 2001 & & $<41$ & $<31$ \\
\hline Sherwin JE, German & 2002 & & $<42$ & $<32$ \\
\hline Tietz NW, Italian & 1995 & & $<45$ & $<34$ \\
\hline Gerhard Schumann, German & 2002 & & $<45$ & $<34$ \\
\hline Kiyoshi Ichihara, Japan & 2007 & & $<45$ & $<34$ \\
\hline Nazarenko G.I. and others Russia & 2002 & $7-40$ & $7-40$ & $7-40$ \\
\hline Zolotavina ML, Russia & 1996 & $<11.4$ & $<11.4$ & $<11.4$ \\
\hline Nikiforof AP, Russia & 1985 & $6.5 \pm 1.95$ & & \\
\hline Lukicheva TI, Russia & 1997 & $46.9 \pm 2.9$ & & \\
\hline Lifshits VM, Russia & 1998 & $<40.0$ & & \\
\hline Kamyshnikov VC, Russia & 2000 & $5.0-30.0$ & & \\
\hline Menshikov VV, Russia & 1987 & $6.0-40.8$ & & \\
\hline
\end{tabular}

Men's blood ALAT level in Mongolian man is higher than women in all ages. It was approved that ALAT level depends on the age by Student $\mathrm{t}$ assessment methods, which is statistically significant $<0.0001$. In addition, correlation coefficients between these two parameters shows $\left[\mathrm{r}=0.158^{* *}\right]$ that the age of the Mongolians and the ALAT level have strong correlation. And as the age progresses, the activity of ALAT have tendency to grow at a normal level. It is similar to results of study [13-15], which approved that ALATenzymes level increases with aging. But concept of study conducted by the Mongolian Medical Institute in 1992, that ALAT level within 16-35 years old population is higher (29.4-30.0 U/L) is not approved by our study. The study of American researches Siest in 1975, and J.Brian's in 2003 is a very interesting [16-22]. The ALAT level is increased by aging achieving 30-40 in males and in age 5060 in women achieved maximal level, after that slowly decreased. According to our study, ALAT level in men 46 year old and in women 54-60 years old have tendency to decrease within normal range. According to J.Brian studies, the activity of ALAT enzyme in men increased from 53-62 U/L in age of 16-45 years, and in age over 80 gradually decreased to $30-33 \mathrm{U} / \mathrm{L}$.

Within women from 16 to 50 years of age ALAT level increased to $36-40 \mathrm{U} / \mathrm{L}$ and it has gradually decreased to $30 \mathrm{U} / \mathrm{L}$ in age 71-80 and achieved $27 \mathrm{U} / \mathrm{L}$ in age over 80 . According the results of $\mathrm{t}$ tests, the ALAT enzyme activity has no significant difference $p=0.247$ within regions. This is similar with the studies of Kiyoshi Ichihara (2007) provided in the six Asian cities, and made conclusion that the blood serum ALAT activity is not different in different regions. The study conducted by Mongolian Medical Institute in 1992 distinguished that ALAT enzyme level within population of Gobi region 32.4 U/L, 39.0 U/L in the Altai mountainous region, 20.2 $\mathrm{U} / \mathrm{L}$ in the steppe and Khangai region and $28.8 \mathrm{U} / \mathrm{L}$ in Ulaanbaatar. This study did not find the cause of differences in regions. The results of our research are different. In addition, the study did not provide a cause for regional differences. There are not many studies assessed ALAT level in different regions of country. Researchers in other countries do not have anything to mention about the seasonal disparity of ALAT enzyme. According to the study of Mongolian Medical Institute in 1992, the ALAT enzyme was the lowest in the winter (21 U/L) and the highest in the autumn (34.2 U/L). This results are different from our study. Research of the Mongolian Medical Institute is based on chemical analysis by Raymond Frenkel, which may be caused error due to the measurement in low temperature in winter. It has been proven that the reagent producer recommendations for the multiplication of results with a coefficient of $370 \mathrm{C}$ if the measurement of temperature was low.

\section{Conclusion}

a) The mathematical average activity of ALAT enzymes in the blood of the Mongolians' serum is $23.55 \pm 0.29 \mathrm{U} / \mathrm{L}$ with significance of $\mathrm{P}=0.95$, and the minimum and maximum reference value are 4.55-42.55 U/L.

b) ALAT enzyme activity correlated with sex, and it is higher in adult males ( $p<0.0001)$ The ALAT enzymes in the blood 
serum of Mongolians changes according to the age $(p<0.0001$, $r=0.158)$.

c) ALAT enzymes level do not have differences in different regions of Mongolia. $(\mathrm{p}=0.247)$.

\section{References}

1. Nazarenko GI, Kiskun AA (2000) Clinical evaluation of laboratory results. Moscow The medicine, pp. 161-192.

2. Menhtyvshin N, Khadkhyy V (1992) Lovekh hemzhee togtooh arg zay. UB 2(36): 40-43.

3. Kamyshnikov VS (2000) Reference book on clinicobiochemical laboratory diagnostics, pp. 351-484.

4. Menshikov VV (1987) Reference laboratory research methods in the clinic. Moscow. The medicine, pp. 181-209.

5. Debbi A, lawlor, Naveed Satter (2005) The Associations of Physical Activity and Adiposity with Alanine Aminotransferase and GammaGlutamyltransferase. Am J Epidemiol 161: 1081-1088.

6. Lustig V (1977) Activation of alanine aminotransferase in serum by pyrodohal phosphate. Clin Chem 23: 175-177.

7. ECCLS (1989) Determination of the catalitic activity concentration in serum of L-alanine aminotransferase (EC 2.61.2,ALAT). Klin Chem 20 204-211.

8. Bergmeyer HU, Horder M, Rej R (1985) Approwed recommendation on IFCC methods for the measurement of catalytic concentration of enzymes. Part 5. IFCC method for aspartate aminotrasferase. J Clin Chem Clin Biochem 24: 497-510.

9. Franca Pagani, Mauro Pantefhini (2001) Biological variation in Serum activities of Three hepati enzymes. Clinical Chemistry 47: 2.

10. Tietz NW (1995) Clinical Guide to Laboratory Tests. 46(51): 286.

11. Sherwin JE (1984) Liver function. In: Kaplan LG Pesce AJ (Eds.), Clinical Chemistry theory, analysis, and correlation. St. Louis: Mosby, pp. 420438.

12. Moss DW, Henderson AR, Kachmar JF (1987) Enzymes, In: Tietz NW, ed.Fundamentals of Clinical Chemistry. ( $3^{\text {rd }}$ edn.). Philadelphia: WB Saunders, pp. 346-421.

\section{ISSN: 2574-1241}

DOI: 10.26717/BJSTR.2019.16.002858

Ganchimeg Ch. Biomed J Sci \& Tech Res

(c) (i) This work is licensed under Creative Commons Attribution 4.0 License

Submission Link: https://biomedres.us/submit-manuscript.php
13. Teri A Manollo, Gregory L Burke, Peter J Savage (1992) Sex and RaceRelated Differences in Liver Associated Serum Chemistry Tests in Young Adults in the CARDIA. Study Clin Chem 41(4): 515-518.

14. Edoardo G.Giannini, Roberto Testa, Vincenzo Savarino (2005) Liver enzyme alterarion: a guide for clinicians. CMAJ 172(3): 367-79.

15. Patrick h Dessein, Angela J Woodiwiss, Barry i Joffe (2007) Aminotransferases are associatiated with insu resistance and atherosclerosis in rheumatoid arthritis. BMC Cardiovascular Disorders $7: 31$.

16. Fischbach F, Zawta B (1992) Age-dependent reference limits of several enzymes in plasma at different measuring temperatures. Klin lab 38: 555-561.

17. Kiyoshi ischihara, Yoshihasa itoh (2008) Sources of Variation of Commonly measured Serum Analytes in 6 Asian Cites and Concideration of Common reference intervals. Clinical Chemistry 54 (2): 356-365.

18. Brain J, Bock, Terrence Dolan (2003) The data Warehouse as a Foundation for Population-based Reference Intervals. Am J Clin Pathol 120: 662-670.

19. Bergmeyer HU, Horder M, Rej R (1986) Approved recommendetion (1985) on IFCC methods for the measurement of catalytic concentration of enzymes. IFCC method for alanine aminotransferase. J Clin Chem Clin Biochem 24: 481-495.

20.Gerhard Schumann, Rainer Klauke (2002) New IFCC reference procedures for the determination of catalytic activity concentrations of five enzymes in serum: preliminary upper reference limits obtained in hospitalized subjects.

21. Tietz NW,Wekstein DR,Shuey DF (1984) A two year longitudinal reference range study for selected serum enzymes in a population more than 60 years of age.J Am Geriatr Soc 32: 563-570.

22. Siest G,Schiele F,Galteau MM (1975) Aspartate aminotransferase and alanine aminotransfrase activities in plasma:Statistical distributions,individual variations,and reference values. Clin Chem 21: 1077-1087.

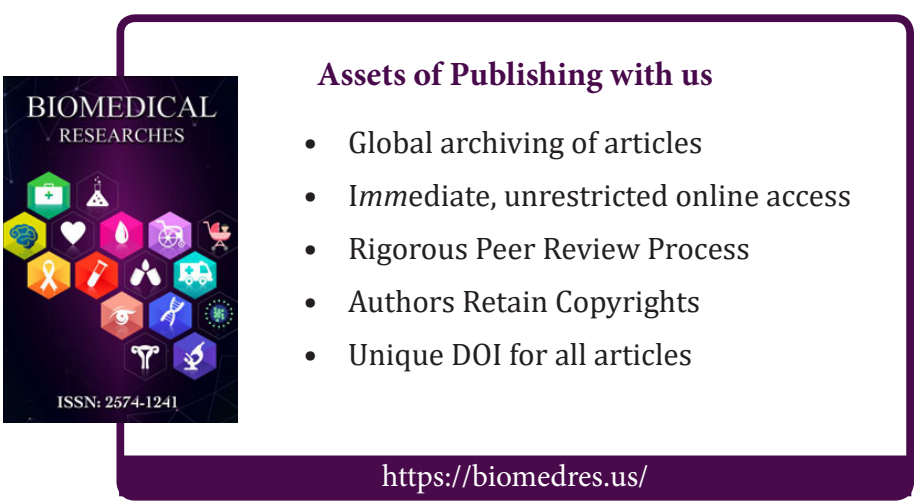

